\title{
3D cartographic modeling of the Alpine Arc
}

Vouillamoz Naomi (1), Sue Christian (2)*, Champagnac Jean-Daniel (3), Calcagno Philippe

(1) Department of Geosciences, Fribourg University, Chemin du Musée 6 - Pérolles

CH-1700 Fribourg, Switzerland

(2) Department of Geosciences, UMR 6249, Franche Comté University, 16, route de Gray, 25000 Besançon, France

(3) Swiss Federal Institute of Technology (ETHZ) Sonneggstrasse 5, CH-8092 Zürich, Switzerland

(4) BRGM, 3 av. Claude Guillemin, 45060 Orléans cedex, France

*corresponding author: Christian Sue, tel: +33 3816661 23. christian.sue@univ-fcomte.fr

\begin{abstract}
We built a 3D cartography of the alpine arc, a highly non-cylindrical mountain belt, using the 3D GeoModeller of the BRGM (French geological survey). The model allows to handle the large-scale 3D structure of seventeen major crustal units of the belt (from the lower crust to the sedimentary cover nappes), and two main discontinuities (the Insubric line and the Crustal Penninic Front). It provides a unique document to better understand their structural relationships and to produce new sections. The study area comprises the western alpine arc, from the Jura to the Northwest, up to the Bergell granite intrusion and the Lepontine Dome to the East, and is limited to the South by the Ligurian basin. The model is limited vertically 10 $\mathrm{km}$ above sea level at the top, and the moho interface at the bottom. We discarded the structural relationships between the Alps sensus stricto and the surrounding geodynamic systems such as the Rhine graben or the connection with the Apennines. The 3D-model is based on the global integration of various data such as the DEM of the Alps, the moho isobaths, the simplified geological and tectonic maps of the belt, the crustal cross-sections ECORS-CROP and NFP-20, and complementary cross-sections specifically built to precise local complexities. The database has first been integrated in a GIS-project to prepare their implementation in the GeoModeller, by homogenizing the different spatial referencing systems. The global model is finally interpolated from all these data, using the potential field method. The final document is a new tri-dimentional cartography that would be used as input for further alpine studies.
\end{abstract}




\section{Introduction}

\subsection{Objective}

The objective of this study is to provide a realistic 3D structural model of the crustal units of the Western and Central Alps at orogenic scale. The complex arcuate and non-cylindrical shape and structural organization of crustal units justifies the development of many alpine 3D models and synoptic bloc-diagrams (e.g. Argand, 1911; Gidon, 1974, Schumacher and Laubscher, 1996; Vignaroli et al., 2008). Seismic tomography in the alpine realm provided the first full-3D structures of the belt based on geophysical data (e.g. Lippitsch et al., 2003; Stehly et al., 2009; Fry et al., 2010). In this paper, we developed a 3D cartographic model of the Western and Central Alps, using state-of-the-art tools and up to date database. The model boundaries have been set within a rectangle that encompasses the alpine arc's realm $\left[5^{\circ} \mathrm{E}\right.$ $\left.10^{\circ} \mathrm{E}\right]$ in longitude and $\left[43^{\circ} 40^{\prime} \mathrm{N}-48^{\circ} \mathrm{N}\right]$ in latitude (Figure $\left.1 \mathrm{a}\right)$. We included within this box the arc of the Western Alps, limited to the South by the Ligurian Sea and the French Rhône valley to the West; the Central Alps up to the eastern Lepontine Dome and Bergell granite to the East; the Jura arc to the North. Vertically, our 3D model is defined between the topographic surface and the moho surface.

The modelized structures mimic the successive Alpine tectonic phases at the crustal scale to build the present-day alpine orogenic wedge (overview in Schmid and Kissling, 2000 and Handy et al., 2010). The various modelized units will be detailed in the following (see part 2). The aim of the model is to address the structural and geometric relationships among the major crustal units. The alpine belt is considered as an independent orogen, and we did not address the relationships with surrounding structures (Rhine graben, Maures massif, Apennines...).

\subsection{Methodology of 3D modeling}

3D structural modeling was performed using the GeoModeller software developed by the BRGM (French geological survey). This interactive software is used to mix all geometrical, geological, and geophysical data available in a same 3D space to complete a geometric 3Dmodel. This method allows to manage data such as a digital elevation model (DEM), structural and geological maps, and geological and geophysical cross sections at all scales. The geometrical coherence of geological interpretations can be checked and insured with this software in 3D during the modeling process. Interpolation of the data is performed using the 
potential field geostatistical method (Lajaunie et al., 1997) by computation of the interfaces location between geological bodies known on the map and sections. These geometrical data and their inter-relations ("EROD" and "ONLAP" relations, see Calcagno et al., 2008 for details) are combined to achieve the geological model. This terminology is used by the GeoModeller software because it has been primirarly designed for sedimentary reconstructions. The result consists in scalar functions (isopotential surfaces) describing the whole $3 \mathrm{D}$ space. Visualization of the isopotential surfaces coming from the interpolation is achieved by the Voronoï diagram method applied to geological objects (Courrioux et al., 2001;Boissonnat and Nullans, 1996). This method transforms isopotential surfaces into discrete sites, which are used to partition 3D space in adjacent cells containing a unique site. Cells are then merged to construct 3D volumes of the geological objects. Either volumes of the geological formations or geological interfaces surfaces can be extracted from these scalar functions (Calcagno et al., 2008). The modelling process is designed to be applied to various geological contexts (Marquer et al., 2006;Martelet et al., 2004;Sue et al., 2010;Joly et al., 2008;Calcagno et al., 2008;Maxelon and Mancktelow, 2005). Finally, the geological model can be used for geophysical forward or inverse modeling (Guillen et al., 2008) or exported for further computations.

At orogenic scale, such 3D geometric reconstruction presents technical limitations: it has been built using only interfaces between different geological body, with position and eventually dip data. Geological objects such as folds and infra-crustal faults could not be modelized at this scale. It is also noticeable that the deep structure of the Alps is inhomogeneously documented. This is especially the case of the southern tip of the belt, which is complex and poorly constrained at depth. Due to the poor constrains available in this area (see cross section in Delacou et al., 2004) and the Alpine-scale of our modeling, the specific crustal structure of the Ligurian Alps and their relation with the piemont bassin are not adressed in this paper, and would deserve a specific study (see Molli et al. 2010 for a review). The accuracy and validity of our model depends on the degree of knowledge availaible.

\subsection{Structural and tectonic framework}

The Western and Central Alps (Figure 1a, 1b) have been created by the subduction of the Tethyan and Valaisan ocean seafloors and the subsequent collision between the European and Apulian margin since the upper Cretaceous (Tricart, 1984;Lemoine et al., 1986). The overall 
structure of the belt is well known at every scales (see review in Handy et al., 2010). At lithospheric scale, the shape and temperature of the European and Apulian lithospheres are pictured by local and telesismic tomography (Kissling, 1993;Okaya et al., 1996;Paul et al., 2001;Lippitsch et al., 2003;Béthoux et al., 2004;Kissling, 2008;Lombardi et al., 2009). The geometry of the crustal nappe stack has been documented by three seismic refraction cross sections, acquired in the 80's (ECORS-CROP (Bayer et al., 1987;Nicolas et al., 1990; Roure et al., 1996), and NFP20 (Pfiffner et al., 1988;Valasek et al., 1991)). These cross-sections reinterpreted by the end of the 90's (Schmid and Kissling, 2000) are the backbone of the present study. The geological macro-structures are especially well known thanks to centuries of mapping and structural interpretation (e.g. Argand, 1916, Figure 1b), see an history in Dal Piaz (2001). This very dense geological mapping and structural interpretation provide inescapable and invaluable constraints on the $3 \mathrm{D}$ reconstruction of the Alpine structure we provide here.

If the arrangement of the various geological units with respect to each other is well documented in cross-sections (2D), the lateral continuation of units and the junction between the classical crustal cross sections is often puzzling and elusive, partly because the western part of the belt is highly curved and non cylindrical.

The arcuate shape of the Western Alps has been debated since decades (Goguel, 1963;Gidon, 1974; Tapponnier, 1977;Tricart, 1984;Laubscher, 1988; Ménard, 1988; Platt et al., 1989; Vialon et al., 1989;Laubscher, 1991; Schmid and Kissling, 2000;Lickorish et al., 2002; Rosenbaum and Lister, 2004). The origin of such bend shape is still unsolved today, and probably result of the interaction through time of a pre-existing bending (the shape of the Mesozoic European margin), together with indentation and counter-clockwise rotation of the Apulian microplate. The rotation of the Apulian microplate is documented for most of the alpine history (e.g. Dercourt, 1986; Dewey et al., 1989) and is still active today (e.g. D'Agostino et al., 2008). The location of the Euler pole of the Adria microplate with respect to stable Europe determined by GPS (Calais et al., 2002; Battaglia et al., 2004; Serpelloni et al., 2007; D'Agostino et al., 2008; Devoti et al., 2008; Weber et al., 2010) and seismotectonics (Anderson and Jackson, 1987; Westaway, 1992; D'Agostino et al., 2008) is located to the NW part of the Po plain, with a counterclockwise rotation of $\sim 0.4^{\circ} / \mathrm{Ma} \pm 0.2^{\circ} / \mathrm{Ma}$. Consequently, the Western and Central do not experience significant shortening anymore, but only transcurrence and extension (e.g. Eva et al., 1998; Sue et al., 1999; Bistacchi et al., 2001; Delacou et al., 2004; Champagnac et al., 2006; Sue et al., 2007; Larroque et al., 2009). 
The goal of this paper is not to discuss the origin of the shape of the belt, but to provide a new perspective of the 3D structure of the Western and Central Alps. Note that the southern termination of the belt could not be modelled with the same accuracy as the rest of the arc, due to the lack of deep seismic sounding.

\section{Input database}

The model is build using several kinds of structural information. The first one is the tectonic map of the Alps published by Schmid et al. (2004), based on the units at the surface. This map has been simplified in a GIS environment, in which we added the alpine DEM as upper limit (GTOPO30), and the alpine moho surface as lower limit (Waldhauser et al., 1998). The second set of data comes from the latest reinterpretations of deep seismic sections ECORS-CROP, NFP20 West and NFP20 East (Schmid and Kissling, 2000). To improve the constraints of these cross-sections, we added three cross-sections, two in the South of the belt (Embrunais and Embrunais-Ubaye) and one across the Jura. A fourth cross-section from Delacou et al. (2004) in the southern tip was tested but not used due to incoherencies with the Waldahauser's Moho model. The third set of data is a local tomography specifically constraining the Ivrea body volume (Paul et al., 2001).

\subsection{Alpine GIS}

The tectonic map of Schmid et al. (2004) has been implemented in ArcGIS 9.1, then simplified in order to allow the 3D modeling process. All the smaller tectonic units have been coherently regrouped with larger ones on paleogeographic bases. From thirty units in the original tectonic map (Schmid et al., 2004), we kept fourteen units to be implemented in the 3D model (Figure 2). The alpine realm has then been divided in three main domains: (i) European-related units (basement, secondary and tertiary covers), (ii) Penninic units (internal Briançonnais basement, Briançonnais cover and Houiller-zone, Piemontais ocean related units, Valais ocean related units, exotic flychs), and (iii) Apulian-related units (Austroalpine nappes North of the Insubric line, Ivrea lower crust, Apulian basement, Southern Alps cover, Tertiary cover), plus (iv) the Bergell granite Tertiary intrusion.

The DEM of the Alps (GTOPO30) has been processed in the GIS using the Reformatter Toolbox (Maxelon, 2004) in order to be compatible with the 3D GeoModeller. 
The moho interface (Waldhauser et al., 1998) was processed the same way. The DEM of the moho gives the lower interface of the 3D model. All data have been projected in the Swiss coordinate system CH10903_LV03 with a grid cell size of $1 \mathrm{~km}$ for the GTOPO30 DEM and $5 \mathrm{~km}$ for the moho elevation model.

\subsection{Deep constraints: alpine cross-sections}

Since upper and lower boundaries of the model are fixed at $+10 \mathrm{~km}$ and $-60 \mathrm{~km}$ respectively, surface data from the tectonic map do not sufficiently constrain the 3D model. Geophysical imagery of mountain belts is thus a key point to provide knowledge on deep structures. Indeed, deep seismic sounding in the 1980's (ECORS-CROP and NFP20 projects) yielded to huge improvements in the alpine geology (Roure et al., 1996;Nicolas et al., 1990;Mugnier et al., 1990;Bayer et al., 1987;Pfiffner et al., 1988;Pfiffner et al., 1997;Valasek et al., 1991). In this study, we exclusively used the up-to-date interpretations of the three profiles ECORS-CROP, NFP20 East NFP20 West by Schmid and Kissling (2000) (see location on Figure 2). These three main and now classical cross-sections have been sketched in a way to match the simplified units of the tectonic map (Figure 3a, b, and c). This was necessary to assure a good internal coherency between the boundaries of the units in map and cross-section. In addition to the fourteen units of the tectonic map, three more geological subsurface bodies are defined: European mantle, European lower crust, and Apulian mantle, including Ivrea Body.

In addition to the three sections well established from deep seismic sounding, we needed three complementary cross-sections to locally constrain our 3D modeling in a backward process (see location on Figure 2). We also integrated a balanced cross-section (Figure 3d) documented by several seismic lines through the Jura belt and the Swiss molasses basin from Sommaruga (1999) and Bonnet et al. (2007). Finally, we used two sections in the southern tip of the arc, the so-called Embrunais-Ubaye area, one drawn from Sue et al. (1999), the other one from Delacou et al., 2004 (Figure 3e and f, respectively). These two sections allow a better constrain of the Penninic Crustal Front (Sue and Tricart, 1999) and determine the behavior of the so-called exotic flysch nappes in that area. Yet, they are only documented by geological mapping, and do not integrate geophysical data. 


\subsection{Ivrea Body's tomography}

We integrated in a final step of the 3D modeling four profiles across the Ivrea Body volume from the local tomography published by Paul et al. (2001). They come from a Pwaves velocity model using local seismicity, designed to specifically image the Ivrea Body and the related lateral velocity variations. This local study allows to precisely characterize the geometry of the Ivrea Body in the southwestern Alps. The tomographic profiles we used are localized on Figure 2.

\section{3D Structural Modeling}

Modeling with the 3D GeoModeller requires specifications about the geological objects to be modelized. First, units must be defined in a stratigraphic-like succession. Secondly, the nature of the contact between each formation needs to be specified following ONLAP/EROD rules (Calcagno et al., 2008). The modeling process follows the given succession of the stratigraphic-like pile. In order to define a coherent pile for the 3D model, a synthetic crosssection of the Alps was created (Figure 4). This synthetic section and the related ONLAP/EROD rules remain valid through the entire 3D model. In our model, we only considered two crustal discontinuities, the Crustal Penninic Thrust (CPT), and the Insubric Line (IL). Technical limitations of the GeoModeller prevented us to modelize these discontinuities as the so-called "fault" objects, which is suitable for smaller discontinuities. Nevertheless, the CPT and IL have been modelized as virtual distinct formations characterized by a nil volume in EROD mode, and called "erosive surfaces" hereafter. In fact, the pile contains units having the same stratigraphic meaning (e.g. European vs. Apulian mantles). The CPT and IL virtual formations divide the 3D model in three distinct domains: the European, the Penninic and the Apulian domains (see section 2.1, Figure 2 and Figure 4) and therefore allow separated modelization for these stratigraphic equivalent units. Thus, including the 14 units of the tectonic map, plus the three deep formation added in the crosssections, and these last two virtual formations CPT and IL, we obtained a global model made of nineteen formations in a stratigraphic-like pile. Each formation is defined by ONLAP/EROD formation with respect to the others.

The 3D modeling begins with loading of the input data (DEM, moho geometry, tectonic map and the six cross-sections) in the delimited model box. Geological objects are then 
defined by contact points in a top mode (digitalized points refer to the top of the lower unit) together with orientation data. Orientation data are automatically computed linked to contact points in cross-sections, but manually fixed on topography following the tectonic map and our own interpretation.

Units are modelized step-by-step following a trial-and-error process, which starts from the base of the stratigraphic-like pile with the European moho's isobaths. The modeling process is divided in six main phases (Figure 4):

1) The European volume;

2) The Penninic front erosive surface;

3) The Penninic volume;

4) The Insubric line erosive surface;

5) The Apulian volume;

6) The Bergell granite.

In order to manage increasing complexity of the ongoing model and handle backward steps, each successive stages of the modelization are saved apart. Note that more than 300 distinct projects were computed to achieve the 3D model of the Western Alpine Arc presented here. 3D volumes are computed with a cell size of $1 \mathrm{~km}$, representing more than twelve million cells for the complete model cube.

\subsection{The European volume: five units in ONLAP rules}

This volume comprises the European mantle, the European lower crust, the European basement (outcropping in the External Crystalline Massifs, ECM), the European Mesozoic cover (including the Jura belt, the French "Dauphinois" subalpine massifs, and the Swiss "Helvetic" nappes), and the European Cenozoic Cover (mainly the Molasse Basin).

The model of the European domain is first calculated with digitized contact point for the five formations in the ECORS-CROP and NFP-20 East/West and the respective unit's limits in the tectonic map. A better delimitation of the European mantle is then obtained by loading the moho's geometry targeted on the specific area. The Jura belt and the most external parts of the Alps are then better constrained using the three additional sections.

\subsection{The Crustal Penninic Thrust: EROD surface}


Since erosive surfaces are modelized as a geological formation they need to meet the following criteria: 1) They must not erode prior formation more than the desired limit and 2) they must have no space for deposition. This balance is obtained by inflating prior units and by adaptation of dipping value of the erosive surface to avoid free volume available for deposition. As for the European volume, the Penninic erosive surface model is first computed after digitized contact point in the ECORS-CROP and NFP-20 profiles. Then the additional Embrunais-Ubaye sections to the South give new constraints allowing a better modelization of the CPT in that area. Finally, the Figure 5 presents the result of the 3D model for the European volume view to the Northwest, with its five units, limited in the inner part by the modeled CPT.

\subsection{The Penninic volume: six units in ONLAP rules}

As for the European volume, the modeling of the Penninic volume is based on the tectonic map, the three deep seismic sections (ECORS-CROP, NFP20 East and NFP20 West), with the same step-by-step process. The additional section from Sue et al. (1999) in the Embrunais-Ubaye area has also been implemented to constrain the Exotic flyschs nappes in the Southwestern Alps. For the coherency of the model, and irrespectively to the geological logic, the stratigraphic-like pile of the Penninic volume follows the synthetic cross-section (Figure 4) and begins from the Exotic flyschs nappes, then the Valaisan unit, the Briançonnais cover, the Briançonnais basement, the Piemont oceanic unit, and finally the Austro-alpines klippes (Figure 2). Two specific complexities appear for the Penninic volume, which are the Prealps klippe, and the Austro-alpine klippes. For modeling purpose, due to the relative size of the geological bodies and their inner complexity, we choose to modelize the Prealps klippe as belonging to the so-called Briançonnais basement formation. Similarly the Austro-alpines klippes must be modelized within the Penninic volume, to allow a coherent stratigraphic-like pile in the further Apulian volume (see below). The Figure 6 gives a sketch of the different units belonging to the Penninic volume.

\subsection{The Insubric Line: EROD surface}

The Insubric Line (e.g. Schmid et al., 1987) plays a similar role for the Penninic volume as the CPT for the European volume. Therefore, the Insubric line erosive surface loses its geological status as a fault to become a splitter surface that separates the European/Penninic 
volumes from the Apulian domain. The IL is also modelized as a virtual geological formation, which allow to create free volume for the further Apulian domain modeling. In the northern part of the belt, the IL has been modelized using the tectonic map and the deep seismic crosssections (ECORS-CROP, NFP20 East and NFP20 West). On the contrary, we had to perform many trial-and-error tests in the southern part of the arc, where this limit is very complex with three adjacent mohos (see Figure 2) and poorly constrained. Actually, we based our model of the IL in this particular area on the moho isobaths (Waldhauser et al., 1998) at depth, and we used the map of the Ligurian sea provided by (Rollet et al., 2002) to document its shallow location. More precisely, we considered the Ligurian moho as a continuation of the Apulian moho. Then, we modelized the European mantle after the moho's isobaths in subduction under the Ligurian and Apulian moho. This approach gives a model of the IL to the South, which remains highly prospective. Actually, the scarcity of the constrains available in this area, together with the larger scale of our model with respect to this more local issue, and with technical matters of the IL modeling (see above), do not allow to better analyze the problem of the Ligurian Moho, South of the belt. Indeed, our model is only based on the Waldahauser's Moho geometry in the southernmost tip of the arc, at the limit of the model. Moreover, local edge effects prevent to better discuss this specific sector. The Figure 7 presents two views of the 3D model, including the geometry of the IL.

\subsection{The Apulian volume: five units in ONLAP rules}

The ECORS-CROP and NFP20 sections with the tectonic map and the moho isobaths give good constraints on this last volume. Actually, the structure of the Apulian volume is quite simple, with a classical stratigraphic-like pile: Apulian mantle, Apulian lower crust, Apulian basement, South-Alps cover, and Tertiary cover of the Pô plain.

Due to the lack of deep cross-section, the crustal indentation of the Ivrea Body is not constrained in the Southwestern Alps. To improve its geometry in that area, we used four sections drawn from the local P-waves tomography of Paul et al. (2001), which show the Ivrea Body indenter in a very high position in the crust. This provides a more continuous Ivrea Body, all along the internal arc of the Alps, as illustrated on the Figure 8.

\subsection{The Bergell intrusion: EROD rule}


The 3D model of the Western and Central Alps is achieved by the modelization of the Bergell granite intrusion. It is constrained by the tectonic map and the NFP20-East section (see supplementary material for illustration of this intrusion).

\section{Discussion and outlook}

\subsection{Limitation of the model}

The main limitation of our model rises up from the large scale we handle. At the whole alpine belt scale, smaller structures (i.e. formally less than ten time the grid size of $1 \mathrm{~km}$ ) cannot be modelized. Detailed relationships between units, as well as structures belonging to each individual modelized volume are beyond the scope of this work. In the same way, available deep constraints are irregularly distributed around the belt. Another important limitation of the final model is due to technical matters, specific to the GeoModeller, especially concerning the EROD/ONLAP features we had to assign. It is also geographically restrained, and further developments should take into account the larger alpine geodynamic context, including the Eastward prolongation of the belt, the peri-alpine rift system, as well as the Alpine-Ligurian sea-Apennines relations, which remains poorly constrained. As for all cartography, our reconstruction includes interpolations, extrapolation and interpretation, and is limited by the existing data.

Nevertheless, our model is the first approach to provide a global 3D view of the Western and Central Alps. It is a key-point for further studies on the Alps, and provides a new tool to improve our knowledge of the belt.

\subsection{D cartographic modeling of the belt}

Our model is a tri-dimensional cartography of the alpine belt. It allows the extraction of any 2D sections as desired, including vertical, oblique and horizontal sections. Figures 9 and 10 present nine examples of vertical (Figure 9) and horizontal (Figure 10) slices extracted from the model. Note that classical cross-sections (ECORS-CROP and NFP20) can obviously be recovered from the model with a good coherency. The main scientific result of our work do not lay in these cross-sections shown as example, but in the model itself, which provides a coherent vision of the main alpines units, including their structures and relationships, and the overall deep structure of the Alps. 
The section 1 Figure 9 (oriented N-S from the northeastern tip of the Jura belt to the Alpine-Apennine junction, see location Figure 10) documents the boundary between European and Apulian domains. This cross-section highlights the relationships among the lithospheres, the lower crusts, and upper crusts (so-called European and Apulian basements) and gives an image of the structures between the ECORS-CROP and NFP20-West sections, through the Sesia zone. At the first order, this section illustrates the indentation of the European lithosphere by the Apulian one. Indeed, symmetric European-related structures are found North and South of the Adria indenter within the European crust and lithosphere. The southern end of the section showing a small part of Adria lithosphere is constrained from the Waldhauser's Moho model in its lower part, but could also corresponds to an edge effect of our model in its upper part; this specific area being rather badly constrained. The Western European part of the section is pretty similar to the classical NFP20-West section, taken slantwise. One could recognize the classical crustal structures, but with a stretching factor with respect to the sections purely perpendicular to the belt's axis.

The section 2 illustrates the European crustal thickening, and the lateral thickening of the Penninic Domain in the saddle between the bulges of the Mont-Blanc and Argentera External Crystalline Massifs: the Penninic Frontal Thrust is thus crossed twice on this section. This NS section is parallel to the section 1, $40 \mathrm{~km}$ to the West. The Apulian indenter disappears in this section for the benefit of the penninic units, mainly made of the basement overlaid by the Piemont oceanic units. Nevertheless, symmetry of the overall structure is beautifully imaged (with an axis in the middle of the penninic units), and is underlined by the uplift of both the Argentera and Mont-Blanc massifs. This section perfectly illustrates the European upper crust's saddle between the Mont-Blanc and Argentera massifs, which allows the penninic to take place. To the north of the section, as for section 1 , one can see the standard relationships (but stretched) between the ECM, the Helvetic/Dauphinois nappes, the Prealps klippen, the Molasses Basin, and the Jura belt.

The section 3 runs E-W from the southern Jura belt to the Bergell granite. It documents mainly European and Penninic units, showing eastward crustal thickening from $30 \mathrm{~km}$ to 60 $\mathrm{km}$. Upper crustal structures in the western part of the section are comparable to the first sections above and to the classical NPF20 and ECORS-CROP sections. Eastward, this section crosscuts the Valaisan area (Penninic units), the Simplon fault, and the larger Lepontine Dome. One can see a structural symmetry between the western limit of the 
penninic nappes (Penninic Frontal Thrust) and their eastern limit (Simplon Fault), although their tectonic roles are opposite (thrust vs. normal fault). The main interest of this section is to document the indentation of the Apulian crust from an unusual viewpoint. Indeed, the front of the Apulian indenter comes inbetween the upper and lower European crust, and its western termination ends underneath the Lepontine Dome. In this area, the crustal "sandwich" is responsible of most of the crustal thickening. Finally, the Bergell granite marks the boundary between the Central Alps (Lepontine Dome) and the Eastern Alps.

Six horizontal slices at five $\mathrm{km}$ interval from $0 \mathrm{~km}$ to $25 \mathrm{~km}$ are shown in Figure 10. The section at $0 \mathrm{~km}$ is very similar to the tectonic map (Figure 2) with exception of the uppermost structures (intramontane basins etc.). The section at $-5 \mathrm{~km}$ depth shows mainly the European, Penninic and Apulian basements, with local basins and slices of Mesozoic cover (e.g. below the Molasse basin) as well as Tertiary Pô basin. At this depth, structural complexity is mostly restrained in the inner part of the arc. The slice at $-10 \mathrm{~km}$ depth shows mainly collisionrelated basement-to-basement contact between Europe and Apulia, with Houiller and Penninic cover pinched by the Ivrea Body vertical indentation. The remnant of the Pô basin appears as an endorheic basin. The slices at $-15,-20$, and $-25 \mathrm{~km}$ depth show the lower crust of the European Plate becoming more and more preponderant with respect to the upper crust. In the innermost part of the arc, the deepest parts of Penninic pinches disappear gradually, which provides a simpler view of the overall collisional system. Note that from the top $(0 \mathrm{~km})$ to the bottom (-25 km) of theses slices, the curvature of the Western and Central Alps evolves toward a less arcuated shape.

\subsection{Further developments}

The scope of this study is to produce and give access to a 3D alpine model, inferred from up-to-date data 3D-modelling tool. This model will be usable by the larger alpine community, as an input for further studies.

A first class of further developments concerns geophysical potential field inversions such as single field (gravimetry inversion) or joint inversion (gravity and seismic velocities for instance). This approach was beyond the scope of this paper, and would ask for a specific analysis (see Martelet et al., 2004 for an example in Brittany). Indeed, such inversions would be natural prolongation of our study, as it could give new constrains on the model, by the use of a new range of data, in a forward-backward process. In the Alps, Masson et al. (1999) published an updated gravimetry map that could be integrated in an evolution of our model. A 
tool of potential field modeling implemented in the GeoModeller would first produce a forward modeling of the gravimetry field, using single density value assigned to each geological body we reconstructed in our 3D-model, to be compared to the map of Masson et al. (1999). A second step would be to proceed an inverse joint modeling of both gravity and seismic data, by readjustments of both the shape of the geological bodies, and of their physical parameters (density, seismic velocities...) (Guillen et al., 2008). Such approach must take into account the non-uniqueness of the geophysical models, as a supplementary constrain. Seismic parameters allow the reconstruction of large-scale 3D structures using tomographic methods (e.g. Paul et al., 2001; Lippitsch et al., 2003; Stehly et al., 2009; Fry et al., 2010). In comparison, our 3D model provides a much smaller definition (about 5-10 km). Tomography based on seismic waves propagation currently provides images mainly at the lithospheric scale. Complementary, our approach, based on tectonic maps and seismic interpreted cross-sections allows management of crustal-scale, and nappe-related structures. Actually, large trends of our 3D model, such as the Moho shape or the collision-related crustal contacts (see above), are in good agreements with the tomographic results (e.g. Stehly et al., 2010).

A second class of applications of our 3D-model of the Western and Central Alps concerns further developments of 3D tectonic and (thermo)mechanical model of the belt, from the collision stages onward, including the final buoyancy-forces-controlled current state of the Alps (see Sue et al., 2007 for a review). 2D tectonic models, in map or cross-sections, have been already proposed (Delacou et al., 2005;Jiménez-Munt et al., 2005; Yamato et al., 2008; Viganò and Martin, 2007), using codes such as ADELI (Hassani et al., 1997) or SHELL (Bird, 1999). Indeed, 3D (termo)mechanical model developed on the basis of our 3D geometrical model used as an input starting point would represent an important step forward in alpine tectonics understanding.

\section{Conclusion}

In this study, we built a 3D structural model of the Western and Central Alps based on DEM, geological maps, crustal cross-sections, Moho isobaths, and local tomography. Thanks to a careful geometrical reconstruction of the structure using the BRGM GeoModeller software, which works in a sedimentary-like fashion (EROD/ONLAP relationships between 
the geological bodies), we provide a novel cartography of the entire Western and Central Alps, including seventeen first-order geological bodies, and two major interfaces (the Crustal Penninic Thrust, and the Insubric Line). This 3D cartography emphasizes the improvements brought by such 3D approach in the understanding of structural relationships at crustal scale, in a highly non-cylindrical belt. Our 3D cartography provides novel views of the belt's structures through unconventional cross-sections, and horizontal sections at depth, and on demand slices in any orientation.

\section{Acknowledgement}

This work has been done with financial support of the Swiss National Science Foundation (SNF) under grants \#200020-101625/1 and \#PZ00P2-126408, and support of the Neuchatel and Besançon Universities, and ETH- Zürich. We are grateful to Stephan Schmid and Silvio Lauer for giving access to their digital maps. Bastien Delacou is acknowledged for providing structural cross-sections. Mahmoud Bouzelboudjen is thanked for providing GIS support. Yolanda Deubelbeiss is warmly acknowledged for sharing her Master's thesis unpublished data. This paper is dedicated to the memory of Martin Burkhard, who initiated and followed the early stages of this study.

\section{Figure captions}

Figure 1: a) Study area of the 3D model of the Western and Central Alps. It is delimited in latitude from $43^{\circ} 40^{\prime} \mathrm{N}$ to $48^{\circ} \mathrm{N}$ and in longitude from $5^{\circ} \mathrm{E}$ to $10^{\circ} \mathrm{E}$, thus enclosing the entire arched part of the Alpine belt together with the Jura belt. b) Early $20^{\text {th }}$ century 3D view of the alpine nappes from (Argand, 1911).

Figure 2: Input GIS database of the 3D model of the Western and Central Alps. Simplified tectonic map, modified from Schmid et al., 2004, in transparency on shaded topography (GTOPO30 DEM) and moho surface model from Waldhauser et al., 1998. Traces of all crosssections used for the 3D modeling are displayed on the simplified tectonic map. Thick black lines represent cross-sections with geophysical constraints (NFP20 East and West, ECORSCROP, Jura, respectively a,b,c and d on Figure 3), whereas thin black lines display sections only documented by geological mapping (Embrunais-Ubaye, Embrunais, respectively e and $\mathrm{f}$ on Figure 3). Red dashed lines give the position of the four tomographic profiles (A-B-C-D) of Paul et al., 2001. These latter are imaged in Figure 8. . 
Figure 3: Deep constraints of the 3D model of the Western and Central Alps with no vertical exaggeration. Three deep seismic sounding interpreted profiles (from East to SouthWest): a) NFP20-East, b) NFP20-West and c) ECORS-CROP, modified from Schmid and Kissling, 2004. d) Balanced cross section constrained by seismic lines across the Jura belt, the Swiss Molasse basin and the Prealps, modified from Sommaruga, 1998 and Bonnet, 2007. e) and f) Geologically documented cross sections across the so-called Embrunais-Ubaye area, modified e) from Delacou et al., 2004 and f) Sue and Tricart, 1999. Legend is similar to Figure 2 plus the European and Apulian mantle and lower crust units. All profiles have been redrawn to match the intersection with the simplified tectonic map (Figure 2) when projected in 3D in the GeoModeller software.

Figure 4: a) Synthetic cross section of the 3D model of the Western and Central Alps that defines the pile of the 3D model. The section and the related ONLAP/EROD rules remain valid through the entire 3D model (see text for details). For modeling purpose, because of relative size of geological bodies, the Prealps klippe is linked to the Briançonnais basement unit. Similarly, the Austro-alpines klippes are defined within the Penninic domain, therefore allowing to maintain a coherent stratigraphic-like pile in the next Apulian domain. b) Inferred stratigraphic-like pile of the 3D model with related ONLAP/EROD rules for each unit. The 3D geometric construction of the model follows the stratigraphic-like succession and is divided in six main phases: 1) European domain with five units in ONLAP mode; 2) The Penninic erosive surface with one unit in EROD mode. Modeling of the Penninic erosive surface allows creation of free space for the further construction of the Penninic domain units. 3) Penninic domain, six units in ONLAP mode, enclosing the Austro-alpines klippes; 4) Insubric line erosive surface, one unit in EROD mode that permits creation of free volume for further modeling of the Apulian domain; 5) Apulian domain, five units in ONLAP mode and 6) The Bergell periadriatic intrusion, one unit in EROD mode which terminates the 3D model construction.

Figure 5: South-Eastern view of 3D model of the European domain (European mantle, European lower-crust, European basement, Secondary cover and Tertiary cover) limited in the inner part by the modeled Penninic erosive surface. Legend is similar to Figure 4. Modeling of the Crustal Penninic Thrust (CPT) allows creation of free space for subsequent construction of the Penninic units. Excess volume of CPT and Tertiary cover (arrows) are removed during the following stages of modeling in particular during the creation of the 
Insubric line interface which eliminates the CPT and Tertiary cover excess volumes within the Penninic domain.

Figure 6: a) to f) Six successive 3D models of the Penninic domain units before modeling of the Insubric line erosive surface. Legend is similar to Figure 4. For each formation, the traces of the constraining cross-section are displayed within the box. g) Southern view of the Penninic volume. Excess volume of the Briançonnais cover unit is removed during the modeling of the Insubric line interface.

Figure 7: North-Western and South-Eastern views of the 3D model of the European and Penninic domains before the 3D construction of the Apulian units. Legend is similar to Figure 4. Modelization of the Insubric line erosive surface allowed creation of free space for subsequent modelization of the Apulian domain units and excess deposit of Briançonnais cover (see Figure 6) has been removed. In the Southwestern part of the Alpine arc, where the structure is very complex but very little constrained, the IL was modelized following the moho's isobaths with the European mantle subducting the Ligurian and Apulian mantles.

Figure 8: South-Eastern views of the 3D Apulian mantle model (displayed with the European basement volume). 1) 3D model of the Apulian mantle constrained by the deep seismic profiles (ECORS-CROP, NFP20-East and NFP20-West). 2) Apulian mantle constrained by local tomography of Paul et al., 2001. A-B-C-D refer to profiles displayed below. 3) Local tomography imaging the Ivrea body in the Southwestern Alps (Paul et al., 2001). The four sections (A-B-C-D) are localized on Figure 2 (red dashed lines) and displayed with no vertical exaggeration. Intersection of the 3D model of the Insubric erosive surface is represented in red lines on the sections. Red dashed lines represent intersection of model only constrained by the deep seismic profiles (ECORS-CROP, NFP20-East and NFP20-West) whereas thick red lines represent intersection of model taking into account the tomography imagery. Use of this new constraint provides a more continuous Ivrea Body, all along the internal arc of the Alps.

Figure 9: A set of three unconventional cross-sections. Sections are located on Figure 10. 1) North-South profile running across the Western Alps arc. The section cuts through the Apulian and Ligurian margins. The profile shows a very complex structure to the South, insufficiently constrained due to the lack of deep geophysical imagery in that area. 2) NorthSouth profile running at the border of the Western Alpine arc, showing symmetrical structures for the European basement and lower crust around the Alpine arc. 3) West-East profile crosscutting the Prealps klippe, the Lepontine Dome and the Bergell granite. The section reveals 
the identation of the Apulian lower crust unit below the Lepontine Dôme. AA: Aar Massif; AR: Argentera Massif; B: Bergell; LD: Lepontine Dome; PA: Prealps; PN: Penninic units; PP: Pô Plain.

Figure 10: Horizontal cross sections of the 3D model box for the first 30 kilometers with five kilometers intervals. Traces of cross-sections used for the modeling are displayed on the maps. Unconventional profiles 1, 2, 3, are represented in Figure 9. Legend is similar to Figure 9.

\section{References}

Anderson, H., and Jackson, J.: Active tectonics of the Adriatic region, Geophys. J. R. Astr. Soc, 91, 937-983, 1987.

Argand, A.: Les nappes de recouvrement des Alpes pennines et leurs prolongements structuraux. , Mat. Carte géol. Suisse 31, 1911.

Argand, A.: Sur l'arc des Alpes occidentales, Eclogae Geologicae Helvetiae, 14, 145-191, 1916.

Battaglia, M., Murray, M. H., Serpelloni, E., and Bürgmann, R.: The Adriatic region: An independent microplate within the Africa-Eurasia collision zone, Geophysical Research Letters, 31, 2004.

Bayer, R., Cazes, M., Dalpiaz, G. V., Damotte, B., Elter, G., Gosso, G., Hirn, A., Lanza, R., Lombardo, B., Mugnier, J. L., Nicolas, A., Nicolich, R., Polino, R., Roure, F., Sacchi, R., Scarascia, S., Tabacco, I., Tapponnier, P., Tardy, M., Taylor, M., Thouvenot, F., Torreilles, G., and Villien, A.: $1^{\text {st }}$ results of a deep seismic profile through th eWestern Alps (ECORS-CROP program), Comptes Rendus de l'Academie de Sciences - Serie IIa: Sciences de la Terre et des Planetes, 305, 1461, 1987.

Béthoux, N., Sue, C., Paul, A., Virieux, J., Cattaneo, M., Fréchet, J., and Thouvenot, F.: Local tomography and focal mechanisms in the southwestern Alps: Comparison of methods and tectonic implications, Tectonophysics, 2004.

Bird, P.: Thin-plate and thin-shell finite-element programs for forward dynamic modeling of plate deformation and faulting, Computers and Geosciences, 25, 383-394, 1999.

Bistacchi, A., Dal Piaz, G., Massironi, M., Zattin, M., and Balestrieri, M.: The Aosta-ranzola extensional fault system and Oligocene-Present evolution of the AustroalpinePenninic wedge in the Northwestern Alps, International Journal of Earth Sciences, 90, 654-667, 2001.

Boissonnat, J. D., and Nullans, S.: Reconstruction of geological structures from heterogeneous and sparse data, INRIA, France, 24, 1996.

Calais, E., Nocquet, J. M., Jouanne, F., and Tardy, M.: Current strain regime in the Western Alps from continuous Global Positioning System measurements, 1996-2001, Geology, 30, 651-654, 2002.

Calcagno, P., Courrioux, G., Guillen, A., and Chiles, J. P.: Geological modelling from field data and geological knowledge. Part I. Modelling method coupling 3D potential-field 
interpolation and geological rules., Physics of the Earth and Planetary Interiors, 171, 147-157, 2008.

Champagnac, J.-D., Sue, C., Delacou, B., Tricart, P., Allanic, C., and Burkhard, M.: Miocene lateral extrusion in the inner western Alps revealed by dynamic fault analysis, Tectonics, 25, Doi 10.1029/2004tc001779, 2006.

Courrioux, G., Nullans, S., Guillen, A., Boissonat, J.-D., Repusseau, P., Renaud, X., and Thibaut, M.: 3D volumetric modelling of Cadomian terranes (northern Britanny, France): an automatic method using Voronoi diagrams, Tectonophysics, 331, 181-196, 2001.

D'Agostino, N., Avallone, A., Cheloni, D., D'Anastasio, E., Mantenuto, S., and Selvaggi, G.: Active tectonics of the Adriatic region from GPS and earthquake slip vectors, Journal of Geophysical Research B: Solid Earth, 113, 2008.

Dal Piaz, G.: History of tectonic interpretation of the Alps, Journal of Geodinamics, 32, 99114, 2001.

Delacou, B., Sue, C., Champagnac, J.-D., and Burkhard, M.: Present-day geodynamics in the bend of the western and central Alps as constrained by earthquake analysis, Geophysical Journal International, 158, 753-774, 2004.

Delacou, B., Sue, C., Champagnac, J.-D., and Burkhard, M.: Origin of the current stress field in the western/central Alps: Role of gravitational re-equilibration constrained by numerical modelling., Geological Society of London Special Publication, 243, 295310, 2005.

Dercourt et al. (1986). Geological evolution of the Tethys belt from Atlantic to Pamirs since the Lias. Tectonophysics, 123, 241-315.

Devoti, R., Riguzzi, F., Cuffaro, M., and Doglioni, C.: New GPS constraints on the kinematics of the Apennines subduction, Earth and Planetary Science Letters, 273, 163-174, 2008.

Dewey, J. F., Helman, M. L., Turco, E., Hutton, D. H. W., and Knott, S. D.: Kinematics of the western Mediterranean, Alpine tectonics, 265-283, 1989.

Eva, E., Pastore, S., and Deichmann, N.: Evidence for ongoing extensional deformation in the western Swiss Alps and thrust-faulting in the southwestern Alpine foreland, Journal of Geodynamics, 26, 27-43, 1998.

Fry et al. (2010). Layered azimuthal anisotropy of Rayleigh wave phase velocities in the European Alpine lithosphere inferred from ambient noise. EPSL, doi.org/10.1016/j.epsl.2010.06.008.

Gidon, M.: L'arc alpin a-t'il une origine tourbillonaire?, C. R. Acad. Sci. Paris, 278, 21-24, 1974.

Goguel, J.: L'interprétation de l'arc des Alpes occidentales, Bull. Soc. Geol. Fr., 7, 20-33, 1963.

Guillen, A., Calcagno, P., Courrioux, G., Joly, A., and Ledru, P.: Geological modelling from field data and geological knowledge: Part II. Modelling validation using gravity and magnetic data inversion, Physics of the Earth and Planetary Interiors, 171, 158-169, doi: 10.1016/j.pepi.2008.06.014, 2008. 
Handy, M. R., M. Schmid, S., Bousquet, R., Kissling, E., and Bernoulli, D.: Reconciling plate-tectonic reconstructions of Alpine Tethys with the geological-geophysical record of spreading and subduction in the Alps, Earth-Science Reviews, 102, 121-158, 2010.

Hassani, R., Jongmans, D., and Chéry, J.: Study of plate deformation and stress in subduction processes using two-dimensional numerical models, Journal of Geophysical Research B: Solid Earth, 102, 17951-17965, 1997.

Jiménez-Munt, I., Garcia-Castellanos, D., Negredo, A. M., and Platt, J. P.: Gravitational and tectonic forces controlling postcollisional deformation and the present-day stress field of the Alps: Constraints from numerical modeling, Tectonics, 24, 1-15, 2005.

Joly, A., Martelet, G., Chen, Y., and Faure, M.: A multidisciplinary study of a syntectonic pluton close to a major lithospheric-scale fault-relationships between the Montmarault granitic massif and the Sillon Houiller fault in the Variscan French Massif Central: 2. Gravity, aeromagnetic investigations, and 3-D geologic modeling, Journal of Geophysical Research B: Solid Earth, 113, 3-13, doi: 10.1029/2006JB004744, 2008.

Kissling, E.: Deep structure of the Alps-what do we really know?, Physics of the Earth and Planetary Interiors, 79, 87-112, 1993.

Kissling, E.: Deep structure and tectonics of the Valais - And the rest of the Alps, Bulletin fuer Angewandte Geologie, 13, 3-10, 2008.

Lajaunie, C., Courrioux, G., and Manuel, L.: Foliation fields and 3D cartography in geology: principles of a method based on potential interpolation, Mathematical Geology, 29, 571-584, 1997.

Larroque et al. (2009). Active deformation at the southwestern Alps-Ligurian basin junction France-Italy boundary): Evidence for recent change from compression to extension in the Argentera massif. Tectonophysics, doi:10.1016/j.tecto.2008.12.013.

Laubscher, H. P.: The arcs of the Western Alps and the Northern Apennines: an updated view, Tectonophysics, 146, 67-78, 1988.

Laubscher, H. P.: The arc of the western Alps today, Eclogae Geologicae Helvetiae, 84, 631659, 1991.

Lemoine, M., Bas, T., Arnaud-Vanneau, A., Arnaud, H., Dumont, T., Gidon, M., Bourbon, M., de Graciansky, P. C., Rudkiewicz, J. L., Megard-Galli, J., and Tricart, P.: The continental margin of the Mesozoic Tethys in the Western Alps, Marine and Petroleum Geology, 3, 179-199, 1986.

Lickorish, W. H., Ford, M., Bürgisser, J., and Cobbold, P. R.: Arcuate thrust systems in sandbox experiments: A comparison to the external arcs of the Western Alps, Bulletin of the Geological Society of America, 114, 1089-1107, 2002.

Lippitsch, R., Kissling, E., and Ansorge, J.: Upper mantle structure beneath the Alpine orogen from high-resolution teleseismic tomography, Journal of Geophysical Research B: Solid Earth, 108, 2003.

Lombardi, D., Braunmiller, J., Kissling, E., and Giardini, D.: Alpine mantle transition zone imaged by receiver functions, Earth and Planetary Science Letters, 278, 163-174, 2009.

Marquer, D., Calcagno, P., Barfety, J. C., and Baudin, T.: 3D modeling and kinematics of the External zone of the French western Alps (Belledonne and Grand Châtelard massifs, Maurienne valley, Savoie). Eclogae Geologicae Helvetiae, 99, 211-222, 2006. 
Martelet, G., Calcagno, P., Gumiaux, C., Truffert, C., Bitri, A., Gapais, D., and Brun, J. P.: Integrated 3D geophysical and geological modelling of the Hercynian Suture Zone in the Champtoceaux area (south Brittany, France) Tectonophysics, 382, 117-128, 10.1016/j.tecto.2003.12.009, 2004.

Masson, F., Verdun, J., Bayer, R., and Debeglia, N.: A new gravity map of the western Alps and its structural and tectonic consequences, Comptes Rendus de l'Academie de Sciences - Serie IIa: Sciences de la Terre et des Planetes, 329, 865-871, 1999.

Maxelon, M.: Developing a three-dimensional structural model of the lower Lepontine nappes Diss. Naturwissenschaften, Eidgenössische Technische Hochschule ETH Zürich, 2004.

Maxelon, M., and Mancktelow, N. S.: Three-dimensional geometry and tectonostratigraphy of the Pennine zone, Central Alps, Switzerland and Northern Italy, Earth-Science Reviews, 71, 171-227, 2005.

Ménard, G.: Structure et cinématique d'une chaîne de collision: Les Alpes occidentales et centrales, Structure et Cinématique d'une Chaîne de Collision: Les Alpes Occidentales et Centrales, 1988.

Molli, G., Crispini, L., Malusà, M., Mosca, P., Piana, F. and Federico, L. 2010. Geology of the Western Alps-Northern Apennine junction area: a regional review. In: (Eds.) Marco Beltrando, Angelo Peccerillo, Massimo Mattei, Sandro Conticelli, and Carlo Doglioni, The Geology of Italy: tectonics and life along plate margins, Journal of the Virtual Explorer, Electronic Edition, ISSN 1441-8142, volume 36, paper 10, doi:10.3809/jvirtex.2010.00215

Mugnier, J. L., Guellec, S., Ménard, G., Roure, F., Tardy, M., and Vialon, P.: A crustal scale balanced cross-section through the external Alps deduced from the ECORS profile, Deep Structure of the Alps, 156, 203-216, 1990.

Nicolas, A., Hirn, A., Nicolich, R., and Polino, R.: Lithospheric wedging in the Western Alps inferred from the ECORS-CROP traverse, Geology, 18, 587-590, 1990.

Okaya, N., Cloetingh, S., and Mueller, S.: A lithospheric cross-section through the Swiss Alps - II. Constraints on the mechanical structure of a continent-continent collision zone, Geophysical Journal International, 127, 399-414, 1996.

Paul, A., Cattaneo, M., Thouvenot, F., Spallarossa, D., Béthoux, N., and Fréchet, J.: A threedimensional crustal velocity model of the southwestern Alps from local earthquake tomography, Journal of Geophysical Research B: Solid Earth, 106, 19367-19389, 2001.

Pfiffner, O. A., Frei, W., Finckh, P., and Valasek, P.: Deep seismic reflection profiling in the Swiss Alps: Explosion seismology results for line NFP 20-East, Geology, 16, 987-990, 1988.

Pfiffner, O. A., Sahli, S., and Stäuble, M.: Structure and evolution of the external basement massifs (Aar, Aiguilles Rouges/Mt. Blanc), Deep Structure of the Swiss Alps: Results from NRP 20, 139-153, 1997.

Platt, J. P., Behrmann, J. H., Cunningham, P. C., Dewey, J. F., Helman, M., Parish, M., Shepley, M. G., Wallis, S., and Western, P. J.: Kinematics of the Alpine arc and the motion history of Adria, Nature, 337, 158-161, 1989. 
Rollet, N., Déverchère, J., Beslier, M. O., Guennoc, P., Réhault, J. P., Sosson, M., and Truffert, C.: Back arc extension, tectonic inheritance, and volcanism in the Ligurian Sea, Western Mediterranean, Tectonics, 21, 2002.

Rosenbaum, G., and Lister, G. S.: Neogene and Quaternary rollback evolution of the Tyrrhenian Sea, the Apennines, and the Sicilian Maghrebides, Tectonics, 23, 2004.

Roure, F., Bergerat, F., Damotte, B., Mugnier, J. L., and Polino, R.: The ECORS-CROP Alpine seismic traverse, Mém. Soc. Géol. France, 170, 1-113, 1996.

Schmid, S. M., Zingg, A., and Handy, M.: The kinematics of movements along the Insubric Line and the emplacement of the Ivrea Zone, Tectonophysics, 135, 47-66, 1987.

Schmid, S. M., and Kissling, E.: The arc of the western Alps in the light of geophysical data on deep crustal structure, Tectonics, 19, 62-85, 2000.

Schmid, S. M., Fügenschuh, B., Kissling, E., and Schuster, R.: Tectonic map and overall architecture of the Alpine orogen, Eclogae Geologicae Helvetiae, 97, 93-117, 2004.

Schumacher, M. E., and H. Laubscher (1996), 3D crustal architecture of the Alps-Apennines join - a new view on seismic data, Tectonophysics, 260, 349-363.

Serpelloni et al. (2007). Kinematics of the Western Africa-Eurasia plate boundary from focal mechanisms and GPS data. Geophysical Journal International, 169(3), 1180-1200.

Stehly et al. (2009). Tomography of the Alpine region from observations of seismic ambient noise. Geophysical Journal International, doi: 10.1111/j.1365-246X.2009.04132.x.

Sue, C., Thouvenot, F., Frechet, J., and Tricart, P.: Widespread extension in the core of the western Alps revealed by earthquake analysis, Journal of Geophysical Research B: Solid Earth, 104, 25611-25622, 1999.

Sue, C., and Tricart, P.: Late Alpine brittle extension above the Frontal Pennine Thrust near Briancon, Western Alps, Eclogae Geologicae Helvetiae, 92, 171-181, 1999.

Sue, C., Delacou, B., Champagnac, J.-D., Allanic, C., Tricart, P., and Burkhard, M.: Extensional neotectonics around the bend of the Western/Central Alps: an overview, International Journal of Earth Sciences, 96, 1101-1129, 10.1007/s00531-007-0181-3, 2007.

Sue, C., Calcagno, P., Courrioux, G., Tricart, J., Frechet, J., and Thouvenot, F.: Relationships between inherited crustal structures and seismicity in the western Alps inferred from 3D structural modeling, Bulletin de la Societe Geologique de France, 181, 583-590, 2010.

Tapponnier, P.: Evolution tectonique du système alpin en Méditerranée: Poinçonnement et écrasement rigide-plastique, Bull. Soc. Geol. Fr, 19, 437-460, 1977.

Tricart, P.: From passive margin to continental collision: A tectonic scenario for the Western Alps, American Journal of Science, 284, 97-120, 1984.

Valasek, P., Mueller, S., Frei, W., and Holliger, K.: Results of NFP 20 seismic reflection profiling along the Alpine section of the European Geotraverse (EGT), Geophysical Journal International, 105, 85-102, 1991.

Vialon, P., Rochette, P., and Menard, G.: Indentation and rotation in the western Alpine arc, Alpine tectonics, 329-338, 1989.

Viganò, A., and Martin, S.: Thermorheological model for the European Central Alps: Brittleductile transition and lithospheric strength, Terra Nova, 19, 309-316, 2007. 
Vignaroli, G., C. Faccenna, L. Jolivet, C. Piromallo, and F. Rossetti (2008), Subduction polarity reversal at the junction between the Western Alps and the Northern Apennines, Italy, Tectonophysics, 450(1-4), 34-50.

Waldhauser, F., Kissling, E., Ansorge, J., and Mueller, S.: Three-dimensional interface modelling with two-dimensional seismic data: the Alpine crust-mantle boundary, Geophysical Journal International, 135, 264-278, 1998.

Weber, J., Vrabec, M., Pavlovčič-Prešeren, P., Dixon, T., Jiang, Y., and Stopar, B.: GPSderived motion of the Adriatic microplate from Istria Peninsula and Po Plain sites, and geodynamic implications, Tectonophysics, 483, 214-222, 2010.

Westaway, R.: Seismic moment summation for historical earthquakes in Italy: tectonic implications, Journal of Geophysical Research, 97, 1992.

Yamato, P., Burov, E., Agard, P., Le Pourhiet, L., and Jolivet, L.: HP-UHP exhumation during slow continental subduction: Self-consistent thermodynamically and thermomechanically coupled model with application to the Western Alps, Earth and Planetary Science Letters, 271, 63-74, 2008. 


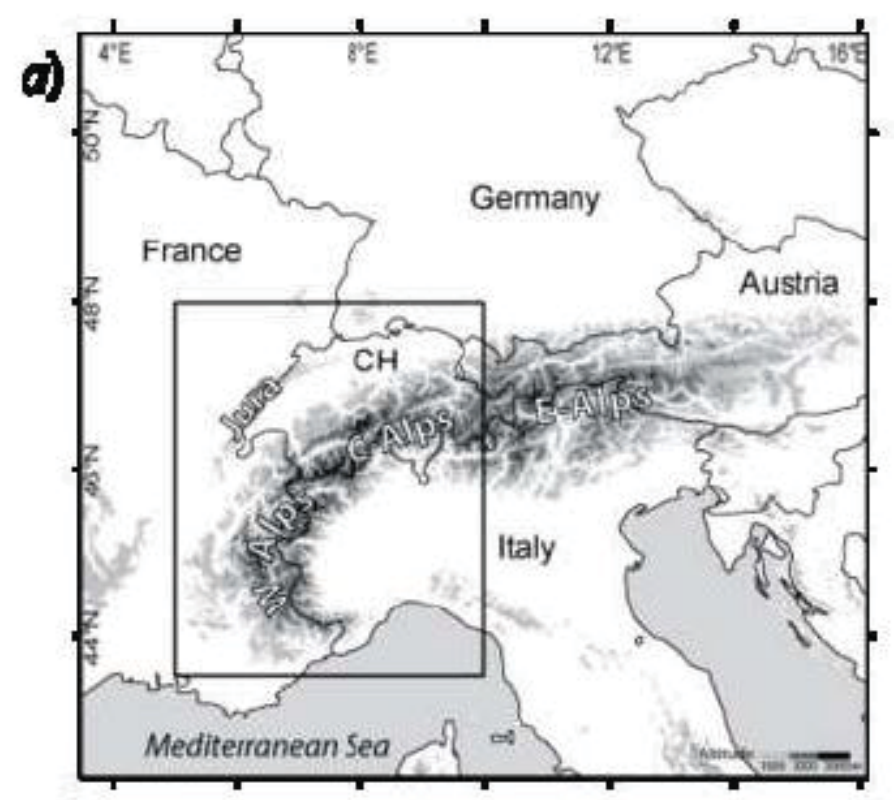

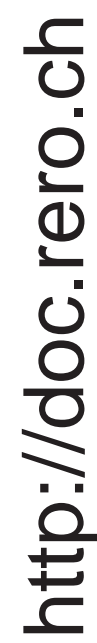

b)

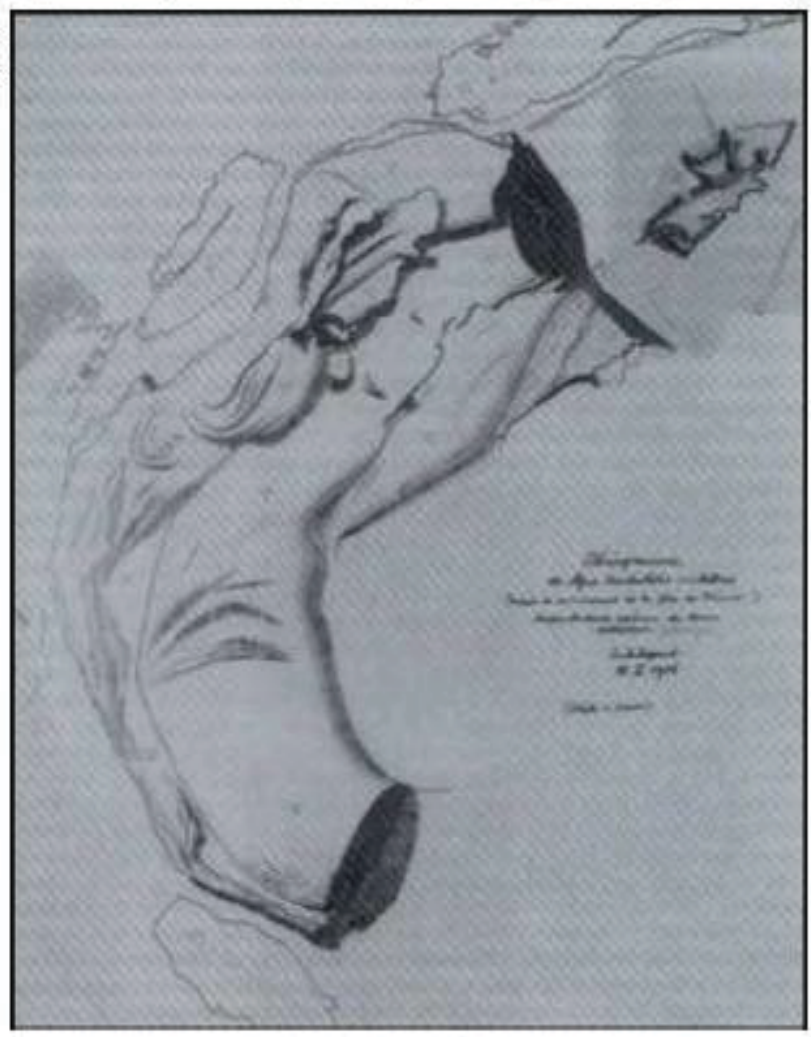

Fig. 1 


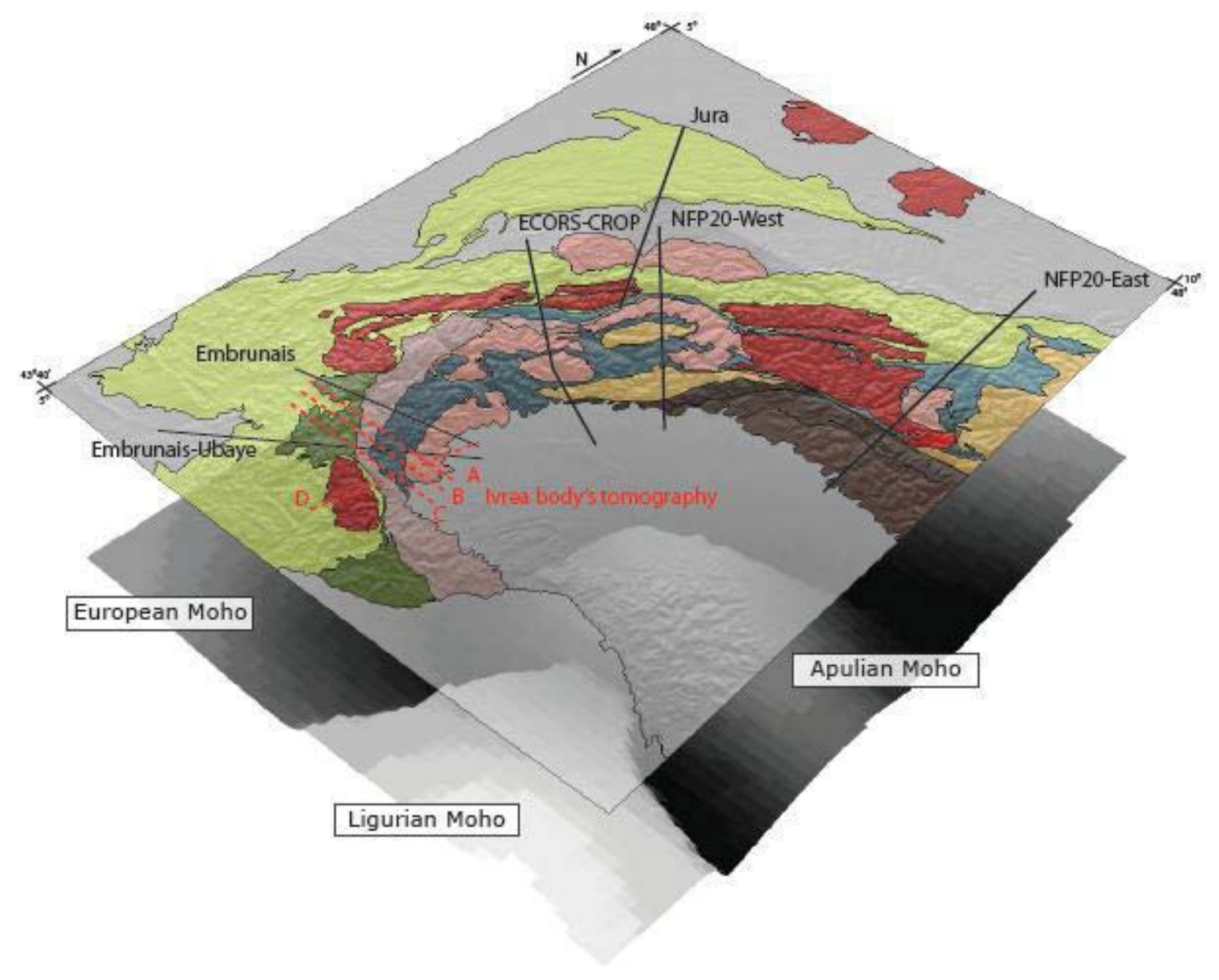

European Margin

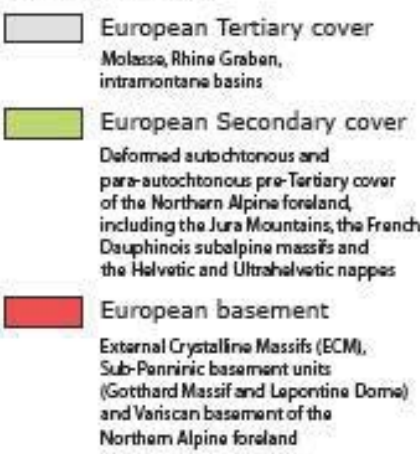

Fig. 2
Penninic domain

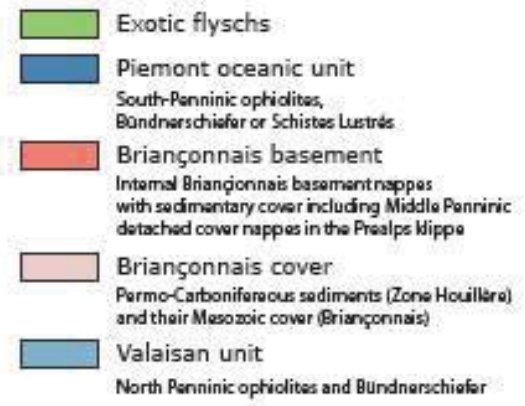

Periadriatic intrusions

Bergell granite intrusion
Apulian Margin North of the Insubric line

\begin{tabular}{|c|c|}
\hline & 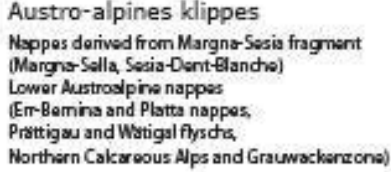 \\
\hline \multicolumn{2}{|c|}{ Apulian Margin } \\
\hline & Tertiary cover of the Pô plain \\
\hline & $\begin{array}{l}\text { South Alps cover } \\
\text { Post-Variscan volcaric and sedimentary cover } \\
\text { of the Southem Alps }\end{array}$ \\
\hline & Apulian basement \\
\hline & Upper crustal basemerk of the Southern Aps \\
\hline & $\begin{array}{l}\text { Apulian lower crust } \\
\text { Lowor crust of the Southern Alps (tvrea) }\end{array}$ \\
\hline
\end{tabular}


Deep seismic sounding interpreted profiles (Modified from Schmid and Kissling, 2000)

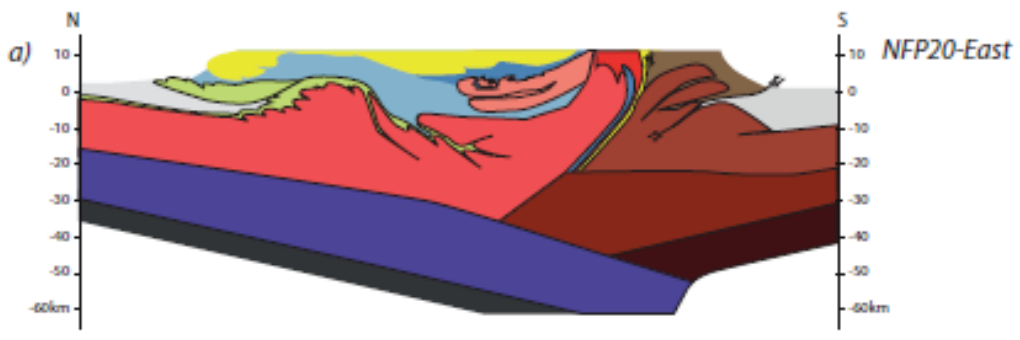

Periadriatic intrusion

Bergell intrusion

\section{Apulian Margin}

$\square$ Tertiary cover of the Pô plain

South Alps cover

Austro-alpines klippes

Apulian basement

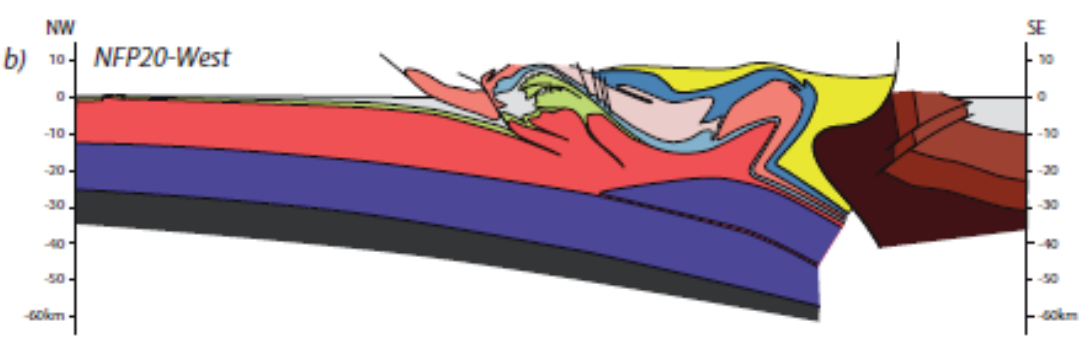

Apulian lower crust

Apulian mantle

\section{Penninic domain}
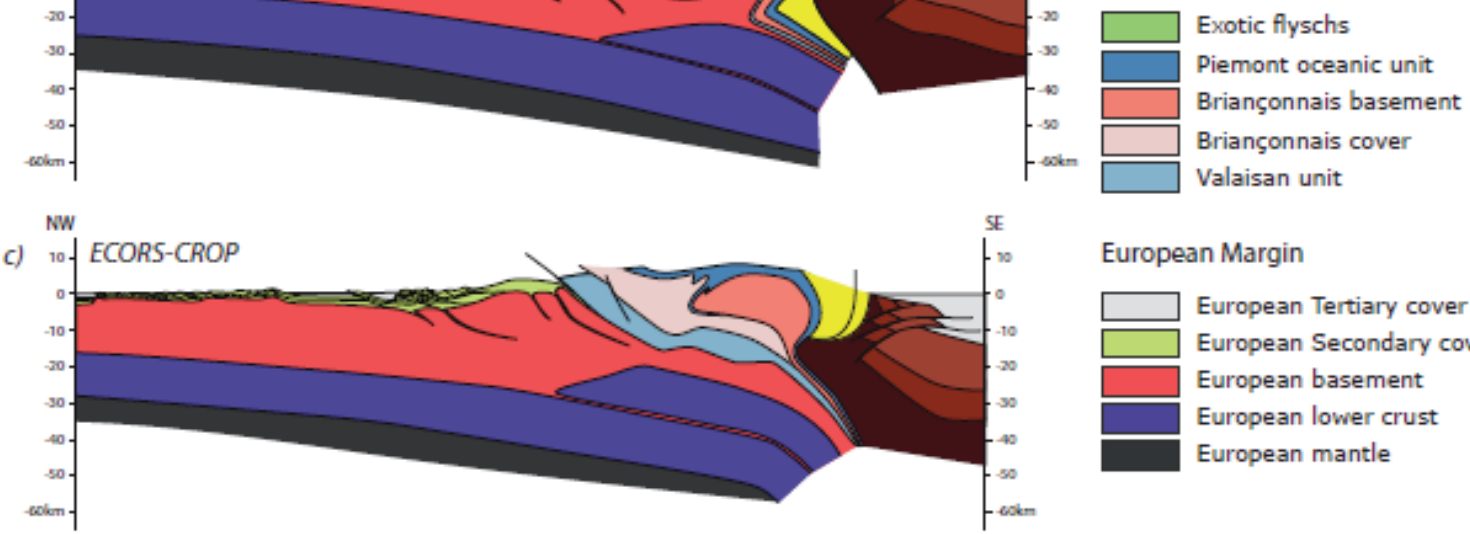

\section{European Margin}

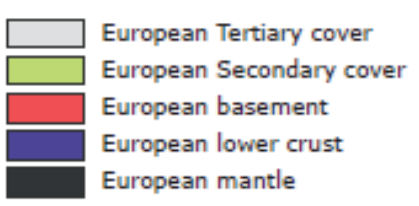

Balanced cross-section documented by seismic lines (Modified from Sommaruga, 1998 and Bonnet, 2007)

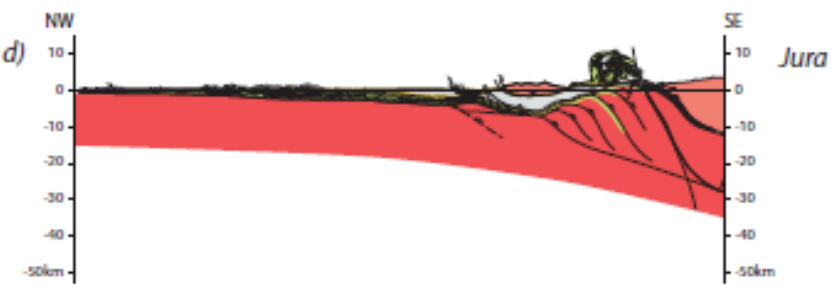

Geologically documented cross-section (Modified from e) Delacou et al., 2004 and f) Sue and Tricart, 1999)
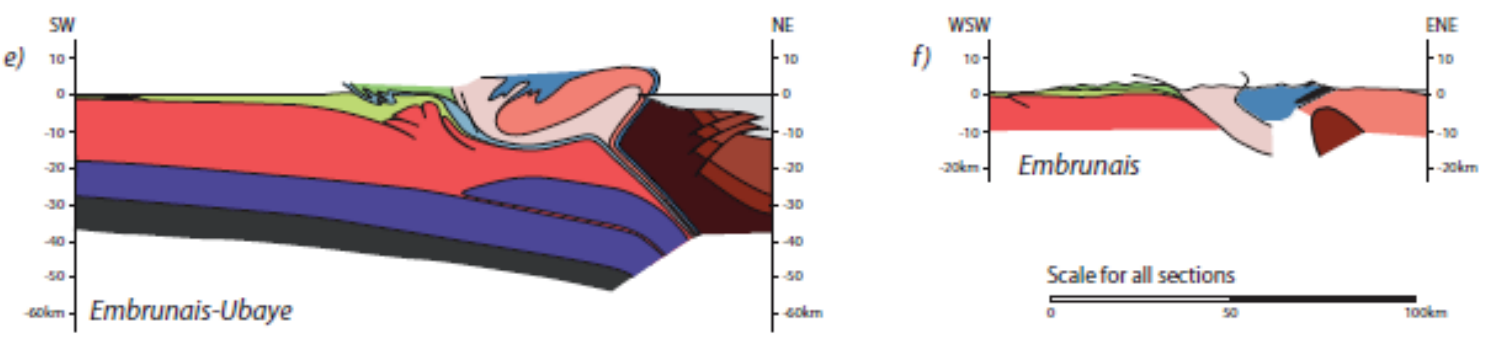

Scale for all sections

Fig. 3 
b) Stratigraphic-like pile of 3D model
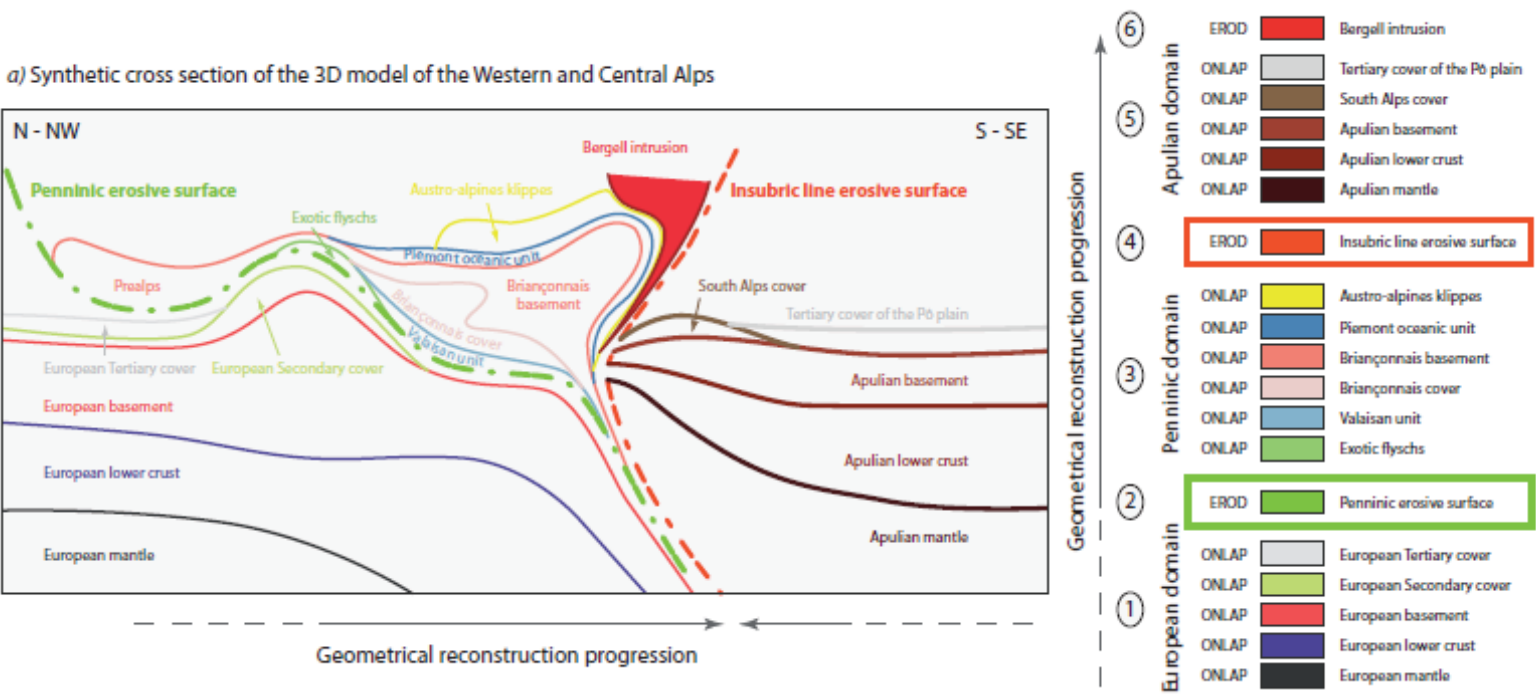

Fig. 4 


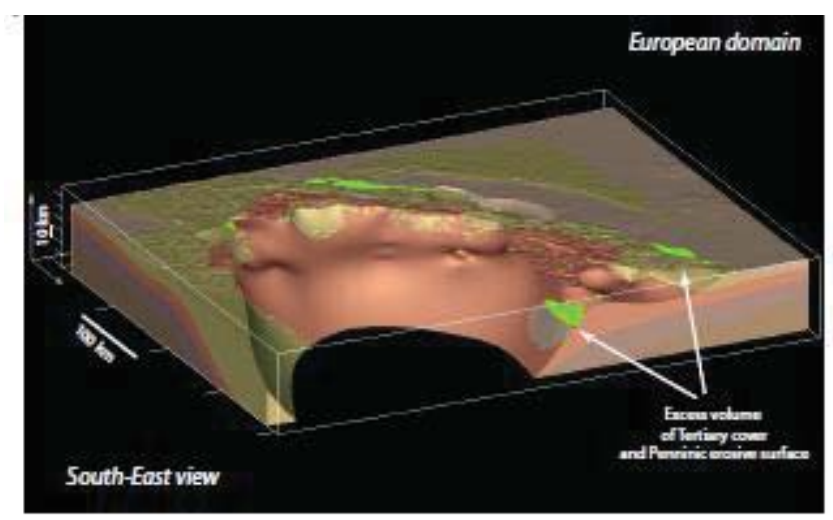

Fig. 5

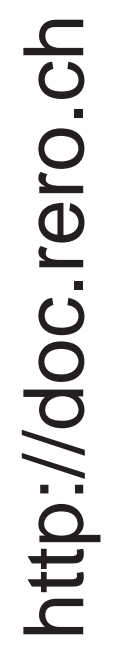




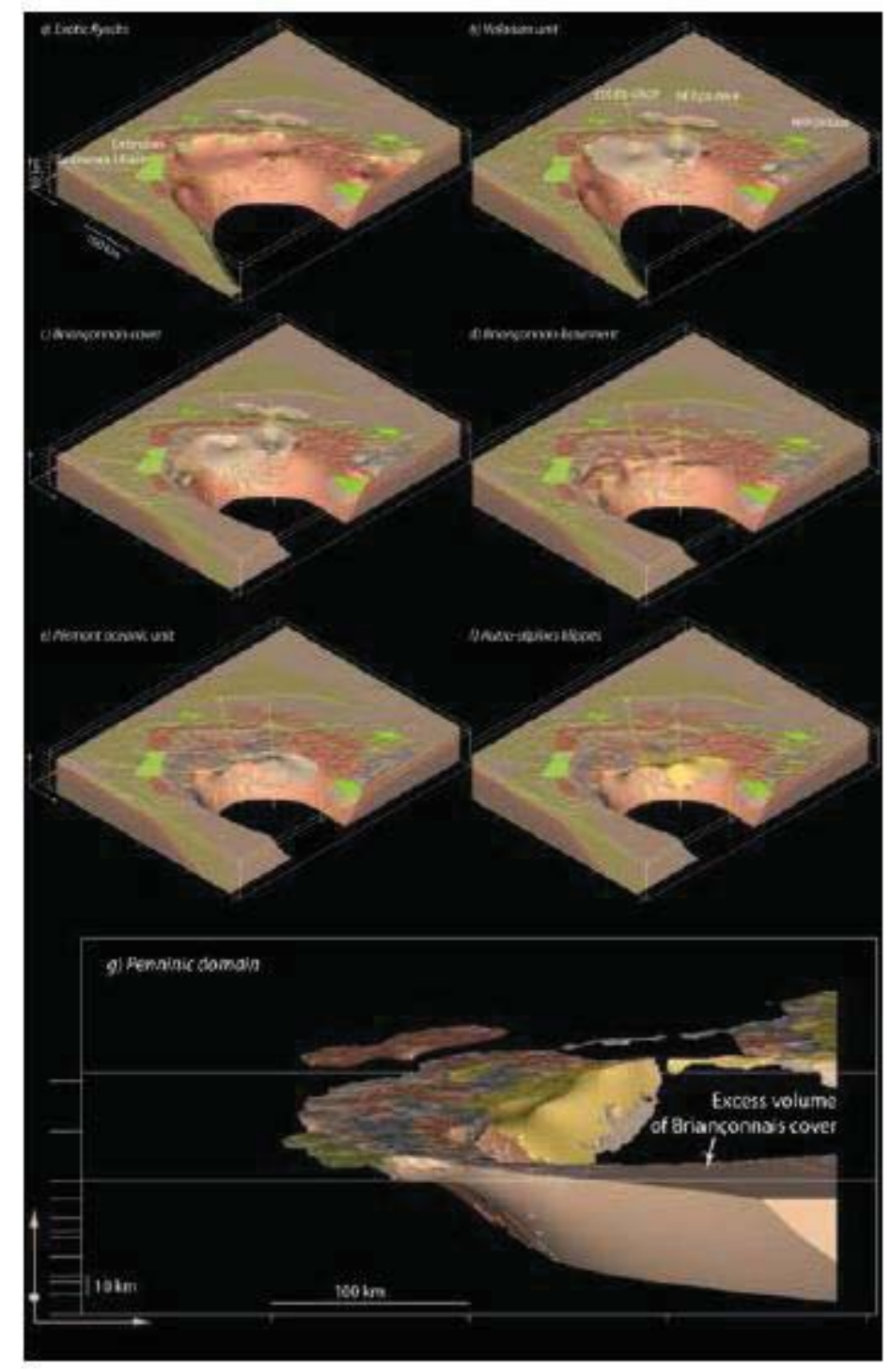

Fig. 6 


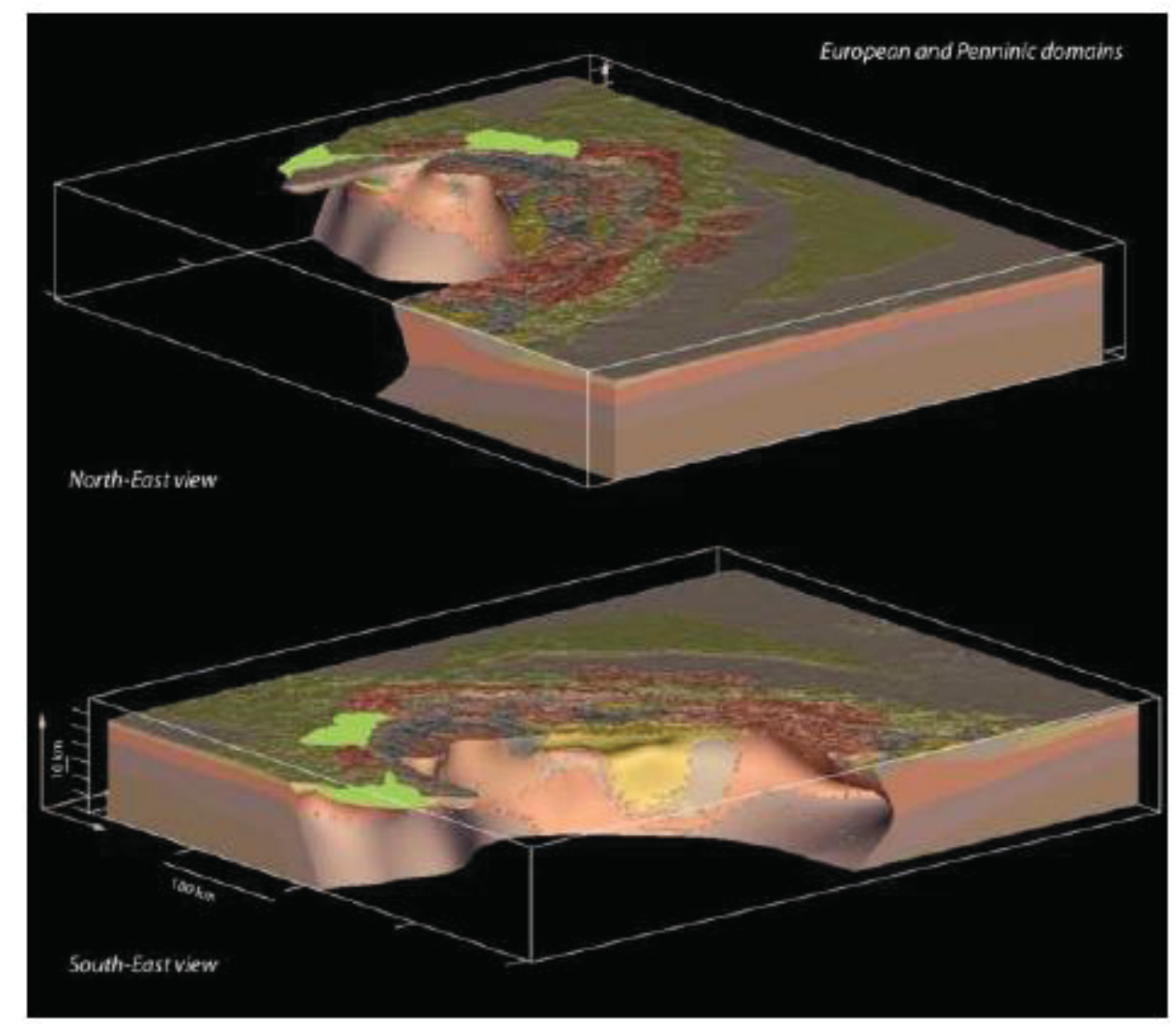

Fig. 7 


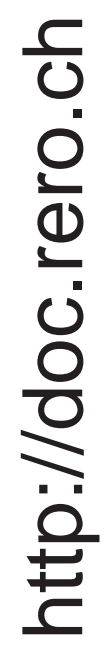

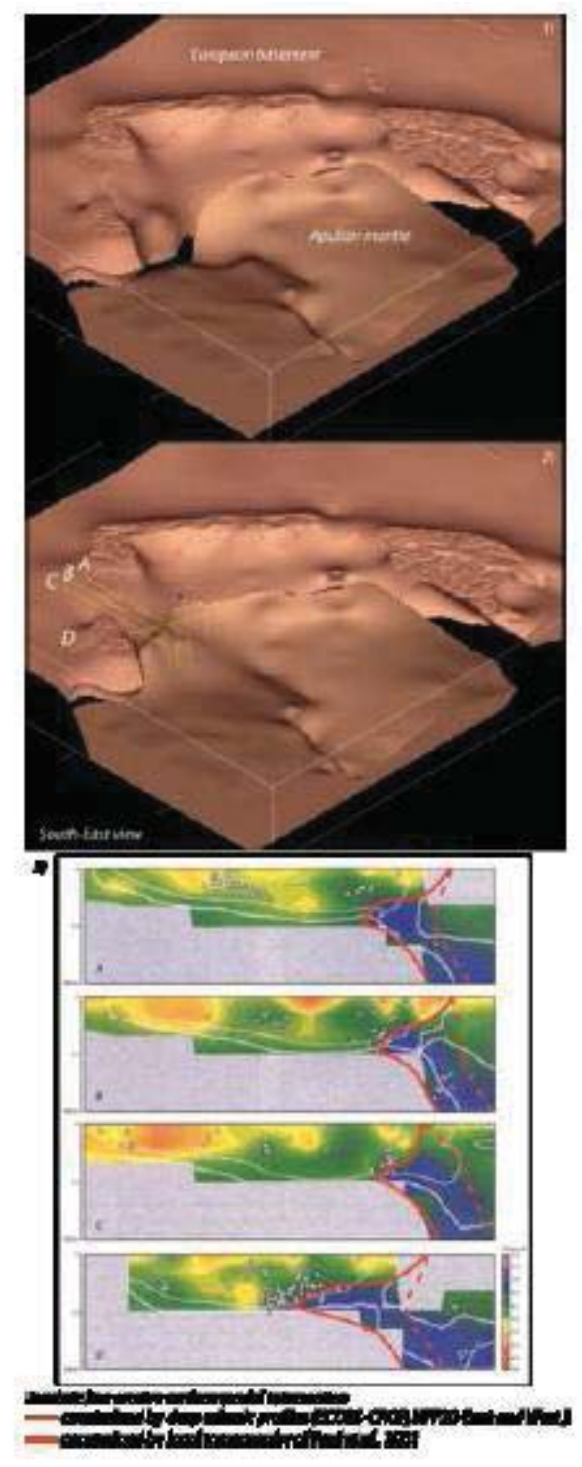

Fig. 8 


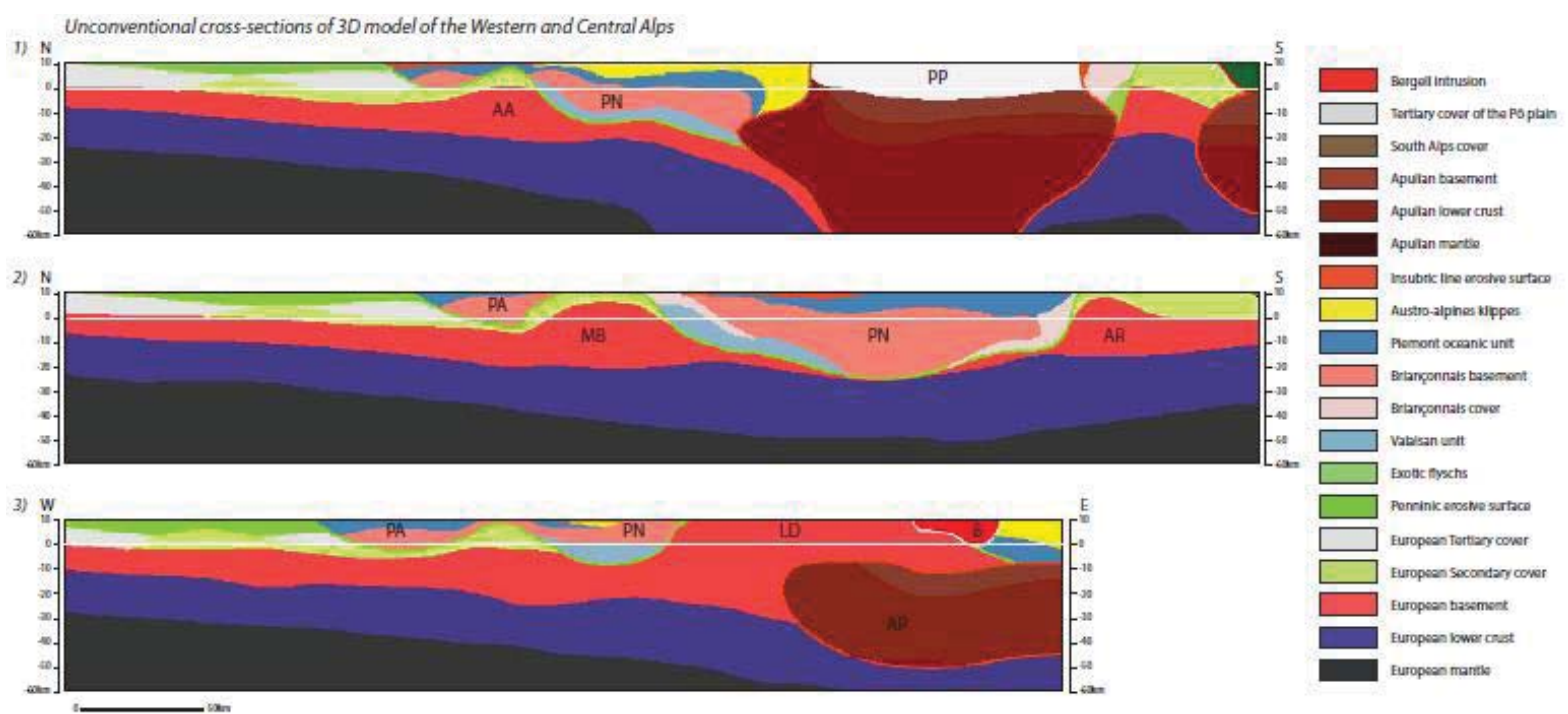

Fig. 9

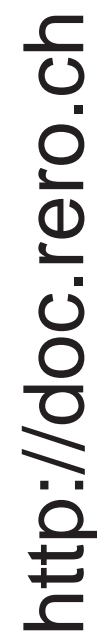



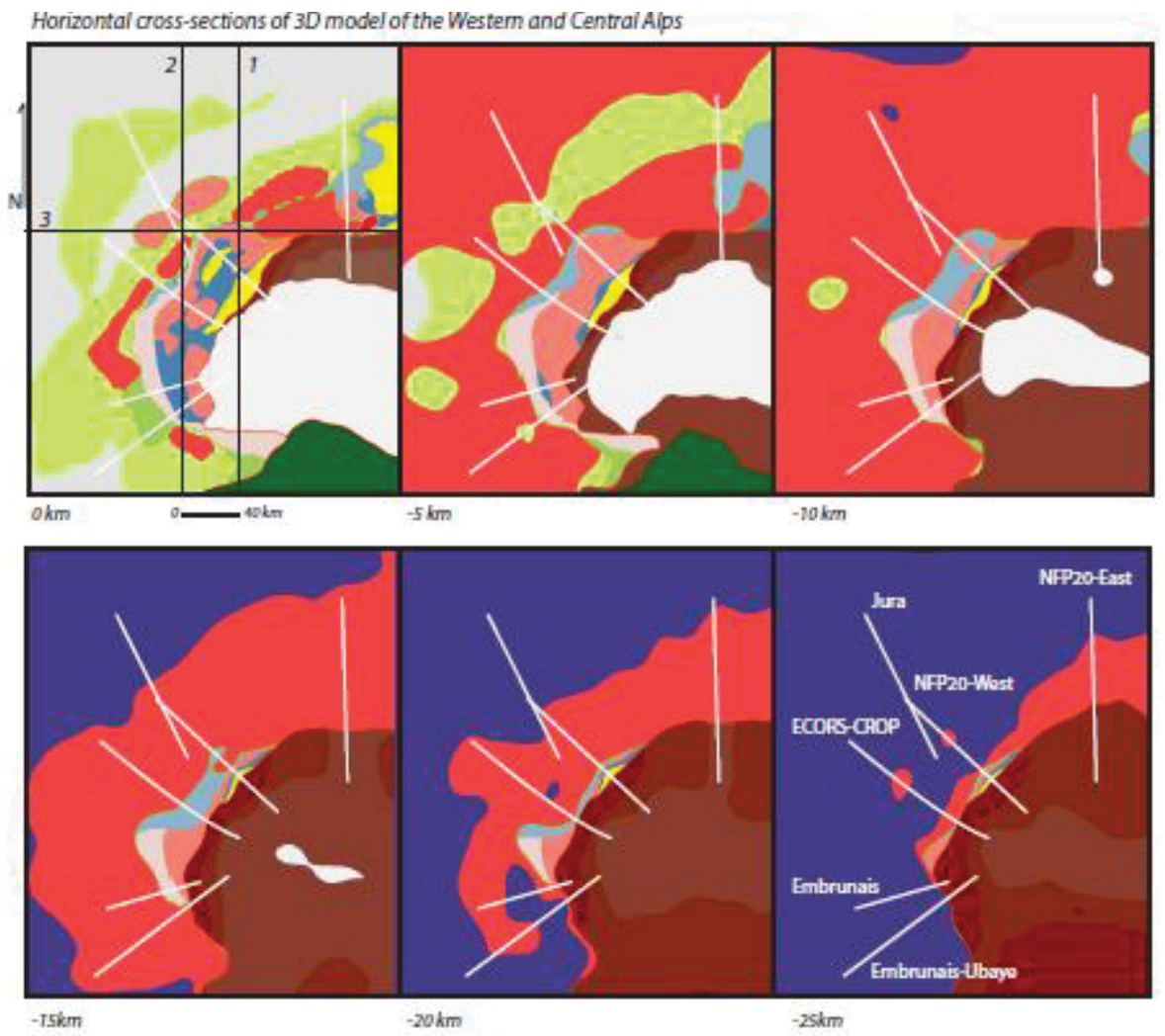

Fig. 10 


\section{Highlights}

We built a 3D structural cartography of the alpine arc

The 3D map is based on the global integration of geophysical and geological data

This cartography provides a fully usable background for cross-section drawing in any orientation. 